\title{
Holding others responsible
}

\author{
Coleen Macnamara
}

Published online: 23 October 2009

(C) The Author(s) 2009. This article is published with open access at Springerlink.com

\begin{abstract}
Theorists have spent considerable time discussing the concept of responsibility. Their discussions, however, have generally focused on the question of who counts as responsible, and for what. But as Gary Watson has noted, "Responsibility is a triadic relationship: an individual (or group) is responsible to others for something" (Watson Agency and answerability: selected essays, 2004, p. 7). Thus, theorizing about responsibility ought to involve theorizing not just about the actor and her conduct, but also about those the actor is responsible to-and specifically about how these people hold the actor responsible for her conduct. In this paper, I give a topology of the terrain of holding others responsible. Over the course of the paper I disambiguate two very broad senses of holding responsibleregarding another as a responsible agent and holding another responsible for a particular piece of conduct. Next, I argue that the latter sense of holding responsible is a genus with two species-what I will call "holding responsible as deep moral appraisal" and "holding responsible as accountability." Appreciating these distinctions, I argue, sheds considerable light on a number of questions concerning the scope and nature of our practices of holding others responsible. Finally, illuminating these distinct senses of holding responsible and highlighting their features reveals an awkwardness in the most carefully explicated and influential account of holding responsible, namely R. Jay Wallace's account in Responsibility and the Moral Sentiments.
\end{abstract}

Keywords Holding responsible $\cdot$ Blame - Praise - Reproof ·

Normative expectation - Reactive attitudes · Participant stance · Appraisal · Accountability

C. Macnamara $(\bowtie)$

Department of Philosophy, University of California, Riverside, HMNSS Building,

Room 1604, 900 University Ave., Riverside, CA 92521, USA

e-mail: coleenm@ucr.edu 


\section{Introduction}

We hold others responsible all the time. A teacher holds her student responsible for his tardiness by giving him detention. A mother holds her daughter responsible for her disrespectful "backtalk" by sending her to her room. A wife holds her husband responsible for not cleaning the kitchen as he promised with her sharp words of rebuke.

Our practices of holding others responsible are of deep practical and theoretical importance; they are of practical import because these practices are a key way by which norms become operative in the world (Reiff 2005), and they are theoretically important because understanding them is key to understanding the concept of responsible agency and the moral life more generally. By some theorists' lights, a theory of holding responsible is crucial to a theory of what it is to be responsible, and to understanding the way in which moral agents are bound not just by norms, but to each other (Wallace 1996; Korsgaard 1996; Darwall 2006; Watson 1996).

But as important and pervasive as this activity is, it is not all that clear what it is to hold someone responsible. What is it about the above interactions that make them count as holding another responsible? And again, what is the extension of the category? If punishments and sharp words count, what about praising someone for her virtuous conduct? Or feeling resentment but keeping it buried in one's heart?

Three things, I urge, have kept us from making more progress here.

First, theorists haven't spent much time trying to make progress. Responsibility theorists have tended to focus on what is to be responsible; as a result, our practice of holding another responsible often falls off their radar screen. Those that do take it up tend to do so only in the context of some larger project. Wallace (1996), for example, puts forth a view of holding responsible in the course of trying to reconcile worries about determinism and responsibility. Oakley (1992) addresses holding responsible in the context of exploring whether and when our emotions are attributable to us. Smith (2007) discusses holding responsible in the course of objecting to Christine Korsgaard and Wallace's "fairness" characterization of the responsibility debate. Watson (1996) puts forward a picture of holding responsible in the process of defending the self-disclosure view of responsibility. And Darwall (2006) explores the practice of holding responsible as a means to arguing for the second-personal nature of morality. All of this has left us with many unanswered questions, and not a small bit of confusion.

Second, discussion has been hampered by an unreflective oscillation between the concepts of holding someone responsible for her conduct and regarding her as a responsible agent. Much of the best literature on holding responsible is indebted to Peter Strawson's famous discussion of the "participant stance"-the stance of engaging with others as agents. Contrasting it with the "objective stance"- the stance we take toward inanimate objects and those people incapacitated in some or all agential respects, the participant stance is the orientation we occupy in ordinary personal relationships (Strawson 1993, p. 55). From this description, it is obvious that we only (properly) hold people responsible from within the participant stance. But discussion has left it deeply unclear what the relationship is between holding someone responsible for her conduct and the participant stance more generally: are they equivalent? different? is the former a part of the whole? 
Third, theorists are keen to emphasize the distinction between merely believing that another's conduct does or does not measure up to some moral standard (what Smart (1961) called "mere grading") and holding another responsible for her conduct. All agree that merely believing that another's conduct is wrong-merely describing the action-does not count as holding that person responsible (see for example Smith 2007; Watson 1996). This distinction is indeed important, but theorists' tendency to focus on it has left underexplored the various senses of holding responsible itself.

In this paper, I give a topology of the terrain of holding others responsible. Over the course of the paper I disambiguate two very broad senses of holding responsible-regarding another as a responsible agent and holding another responsible for a particular piece of conduct. Next, I argue that the latter sense of holding responsible is a genus with two species-what I will call "holding responsible as deep moral appraisal" and "holding responsible as accountability." Appreciating these distinctions, I argue, sheds considerable light on a number of questions concerning the scope and nature of our practices of holding others responsible. Finally, illuminating these distinct senses of holding responsible and highlighting their features reveal an awkwardness in the most carefully explicated and influential account of holding responsible, namely Wallace's account in Responsibility and the Moral Sentiments.

The paper proceeds as follows. In the next two sections, I review the literature on holding others responsible, drawing attention to the confusion and questions that it engenders. In Sects. 4 and 5, I present my picture of the terrain, explaining how key distinctions help to clarify the scope and nature of our practices of holding responsible. In the final section I turn my attention to Wallace arguing that if my portrayal of the appraisal and accountability faces of holding responsible is correct, then his account looks rather like mishmash: it takes some features from the accountability face and some from the appraisal face and throws them together.

\section{Strawson's legacy}

Let's start where most of those who discuss holding responsible do: Strawson's seminal article "Freedom and Resentment." In this article, Strawson gives an account of the participant stance. ${ }^{1}$ This stance, Strawson tells us, is the stance we take toward those we believe to be capacitated agents, or better, members of the

\footnotetext{
${ }^{1}$ Implicit in Strawson's work is the distinction between the participant stance and the participant reactive attitudes. The former is the complex mental orientation we take toward another which modulates our patterns of salience, presumptive interpretations, and leaves us susceptible to certain emotions and types of interactions. The participant reactive attitudes are those distinct emotional states we are susceptible to when we adopt the participant stance: friendly affection, sympathy, gratitude, hurt feelings, disappointment, resentment, and indignation. Strawson, however, never explicitly draws the distinction between the participant stance and participant reactive attitudes; and in fact, he never employs "stance" language at all. Strawson simply uses the singular "participant attitude" to refer to what I am calling the participant stance and the plural "participant attitudes" to refer to participant reactive attitudes. I import "stance" language into my analysis of Strawson because it both accurately captures Strawson's view and adds clarity.
} 
moral community. To adopt this broad psychological orientation toward another is to regard another as a responsible agent, where such regard is understood as more than a matter of simple belief. It is a broad orientation that guides our presumptive interpretations of the person's conduct-for example, we presume until presented with evidence to the contrary that the person is responsible for her conduct. It also structures our behavioral dispositions - we are disposed, for example, to offer and ask for reasons from the other. And it structures our emotional proclivities. ${ }^{2}$ In particular, Strawson stresses the link between regarding someone as a responsible agent and feeling a wide range of what he calls "reactive attitudes." These include friendly affection, sympathy, adult reciprocal love, gratitude, hurt feelings, disappointment, resentment, indignation, approval, disapproval, admiration, and forgiveness.

Strawson contrasts the participant stance with the objective stance-the stance we take toward inanimate objects or individuals deemed "incapacitated in some or all respects for ordinary interpersonal relationships" (Strawson 1993, p. 55). To adopt the objective stance toward another is to regard her "as an object of social policy" as something to be acted upon rather than engaged, as something to be "managed or handled or cured or trained." And though the objective stance is emotionally toned-one may pity, or fear, or even, in some ways, love the object of the stance-it does not include the range of reactive attitudes- "resentment, gratitude, forgiveness, anger, and the sort of love which two adults can sometimes be said to feel reciprocally for each other" (Strawson 1993, p. 52).

One of Strawson's points, then, is that there are a number of attitudes (e.g., adult reciprocal love, resentment, approval) and activities (e.g., asking someone the reasons behind her action, accepting another's promise, and offering another confidences, punishing another for her wrongdoing) that go hand in hand with regarding another as a responsible agent as opposed to an object. Let's call these activities and attitudes "participant attitudes and activities." Of all the various participant attitudes and activities the ones that Strawson emphasizes the most are the reactive attitudes.

Indeed, Strawson has a tendency to focus on those reactive attitudes that are forms of praise and blame. When I disapprove of my friend for disrespecting her mother, or resent my date for standing me up for the second time, or feel indignation toward the perpetrator of a hate crime, I am by most theorists' lights blaming the wrongdoer (see for example, Wallace 1996; Watson 1996; Scanlon 2008). Or again when I feel gratitude when my friend does me a favor, admiration when my sister volunteers at a soup kitchen, or approval when I witness a stranger perform a small act of kindness, I am praising my friend, my sister, and the stranger.

In the course of discussing responsibility, many theorists point to the above reactive attitudes - to disapproval, resentment, indignation, approval, admiration, gratitude and their expressions-as the key components of our practice of holding others responsible (see for example Wolf 1990; Fischer and Ravizza 1998). For these theorists, we hold others responsible when we respond to their kind deeds with

\footnotetext{
${ }^{2}$ My articulation of Strawson's participant stance is indebted to Little (1998). In this article, she doesn't discuss Strawson, but stances more broadly.
} 
gratitude and approval, or when we express these emotions in embraces, smiles, and words of adulation; or again, when we blame them for an act of wrongdoing, when we feel resentment, indignation, disapproval, or express these emotions in stern looks, reprimands, and rebukes. In short, for many, to hold others responsible is to respond to their conduct with praise or blame, in either their expressed or unexpressed form.

One of the most carefully explicated theories also focuses on the reactive attitudes and their expression, but with a decided shift to the negative. Wallace argues that we need to drastically narrow the class of the reactive attitudes relevant to holding responsible (see Wallace 1996, Chaps. 2 and 3). For Wallace, the class of other-regarding reactive attitudes relevant to this issue is made up of resentment and indignation. These emotions alone, not the wide range of attitudes Strawson identified, are key, according to Wallace.

For Wallace, though, we need not literally be feeling resentment or indignation to count as holding another responsible. He highlights the propensity or orientation that leaves us susceptible to these emotions, what I will call "normative expectation." 3 To get a sense of normative expectation and its connection to resentment and indignation, consider Aidan. Aidan commutes to work by subway, and while he enjoys not having to drive, he often finds his subway rides unpleasant. Aidan lives in a city where people regularly flout the norms that govern entering a subway car. Riders boarding a subway car too often violate the ought of stepping aside and letting the people exit before trying to board. As a result, Aidan frequently witnesses people pushing their way onto the subway, and has himself been shoved by someone prematurely storming his way on. Each incident fills Aidan with unpleasant negative reactive attitudes; feelings of resentment and indignation quickly take hold. And then there are the times when Aidan cannot resist expressing these emotions. This of course only makes matter worse, for his fellow riders do not always react kindly to Aidan's reprimands.

One day Aidan decides that he has had enough. He vows to do something to make his rides more peaceful. He first tries instituting a no-scolding policy. This helps - testy interactions with his fellow riders are now a thing of the past-but it is no cure-all. For each time Aidan sees a fellow rider push his way onto the subway, he still finds himself besieged by the negative reactive emotions of resentment and indignation, and forced to fight the urge to express these emotions with the fingerwagging and sharp rebukes he foreswore.

Aidan decides to try something more radical-something that promises to prevent resentment and indignation from ever rearing their ugly heads. He decides to mentally disengage, to simply "let go." Put more technically, he decides to eschew the attitude of normatively expecting that his fellow riders wait their turn.

To be clear, Aidan is not now eschewing a predictive expectation. He retains a strongly grounded predictive expectation that other riders will flout the relevant norms. It has been a long time since Aidan thought it likely that his fellow riders would wait their turn (Wallace 1996, pp. 20-21). Nor is he letting go of the belief

\footnotetext{
${ }^{3}$ What I am calling a normative expectation Wallace calls "the stance of holding others responsible" (Wallace 1996, Chap. 2).
} 
that his fellow subway riders ought to wait their turn; he continues to believe that they should. What Aidan is doing is letting go of his normative expectation that others not barge their way onto the subway. It is this attitude that leaves Aidan susceptible to feeling resentment or indignation when they do (Wallace 1996, pp. 18-40). If he eschews this attitude he will no longer be susceptible to feeling indignation and resentment when fellow riders don't wait their turn and thus will be free from the powerful urge to reprove them for their unacceptable conduct. If Aidan pulls it off, he will be free to enjoy his ride to work.

But he won't, according to Wallace, be holding his fellow riders responsible. On Wallace's account holding responsible is situated "within a distinctive nexus of moral concepts, namely those of moral obligations, moral right and moral wrong" (Wallace 1996, p. 64), and holding another responsible amounts to holding her to the ought that binds her (Wallace 1996, p. 66). We do this, according to Wallace, whenever we normatively expect that she do what she ought, resent her or feel indignation toward her when she does not do as she ought, or express these reactive attitudes in a range of sanction responses such as "avoidance, reproach, scolding, denunciation, remonstration, and (at the limit) punishments" (Wallace 1996, p. 54). ${ }^{4}$

Wallace calls his account the "reactive account" of holding others responsible. He chooses this name to mark the fact that, on his account, it is our reactive emotions of resentment and indignation rather than our sanctioning behaviors that lie at the heart of the practice (Wallace 1996, p. 66). While Wallace acknowledges that we hold another responsible when we sanction her, these behaviors are, as it were, the handmaids of the reactive attitudes. As Wallace puts it, "What is essential to the harmful moral sanctions, on the reactive account, is their function of expressing the emotions of resentment, indignation and guilt: this is the real point of such responses as avoidance, denunciation, reproach, censure and the like, and what holds them together as class" (Wallace 1996, p. 68).

Wallace focuses on the reactive attitudes; Watson, in contrast, puts a range of sanctioning behaviors front and center. In "Two Faces of Responsibility," Watson responds to Susan Wolf's criticisms of "real self views" of responsibility. Real self theorists hold that responsibility is defined in terms of the relationship between one's conduct and one's “deepest" values or commitments (Watson 1996, p. 228). In the course of defending these views Watson distinguishes two perspectives on responsibility: the aretaic perspective and the accountability perspective. Each perspective consists of a way of being responsible and a corresponding form of evaluation. The aretaic perspective is associated with the "real self view" of responsibility. Those that are responsible for their conduct in this sense are open to what Watson calls "aretaic evaluation"- - beliefs or judgments about how another's conduct fares against some standard. ${ }^{5}$ In contrast, on the accountability perspective being responsible arguably requires some sort of control, in the sense of the ability

\footnotetext{
${ }^{4}$ On Wallace's account, we also hold another responsible when we believe that resentment or indignation would be an appropriate response to another's moral violation (Wallace 1996, p. 71). I don't mention this detail above because it has no bearing on the arguments of this paper.

5 See Smith (2008) for an excellent discussion of Watson's aretaic evaluation.
} 
to do otherwise, and evaluation amounts to holding another responsible for her conduct.

Watson maintains that "holding responsible is a triadic relation involving two people and a requirement (task, responsibility)" (Watson 1996, p. 236). The first agent is the actor, the one who faces the requirement. The second agent is the one who holds the actor to the requirement she faces by responding to her violation of that requirement. The responses Watson emphasizes are punishment, reproof, rebuke, reprimand, censure and the like. On his view we hold another responsible when we impose, in his words, a "sanction" on her, where a sanction is understood as a form of "unwelcome or adverse treatment" (Watson 1996, p. 237).

Watson is well aware that for many theorists praise and unexpressed resentment and indignation are key components of our practice of holding other responsible, and that on his view they seem to have receded into the shadows of our sanctions. On the topic of unexpressed resentment and indignation he writes, "But how is being subject to a blaming attitude a sanction?" (Watson 1996, p. 238). Our blaming attitudes leave us disposed to engage in unwelcome or adverse treatment, but are they themselves sanctions?

On the topic of praise, he writes:

Like most writers on the subject, I began talking about the connections between responsibility and praise and blame but became preoccupied with the negative case. We seem to have a richer vocabulary of blame than praise. This slant is not due solely to mean-spiritedness. At least part of the explanation is that blaming tends to be a much more serious affair: reputation, liberty and even life can be at stake, and understandably we are more concerned with the conditions of adverse treatment than with those of favorable treatment. (Watson 1996, pp. 241-242)

Or again:

The fact that 'holding responsible' has, strictly speaking, no positive counterpart reinforces the asymmetry. To be held liable is to be on the hook, and we lack a ready phrase for the positive counterpart to the 'hook'. But clearly we do have a counterpart notion; just as (moral) blame is sometimes called for as response to the flouting of (moral) requirements, so praise is an appropriate response to respect for moral requirements, or moral ends. We express praise by recognition: bestowing a medal or more commonly, remarking on the person's merits. ('It was good of you [him] to help'.) (Watson 1996, p. 242)

These comments on praise are made in a discussion of Wolf's as asymmetry thesis, the thesis "that blameworthiness requires avoidability, while praiseworthiness does not" (Watson 1996, p. 241), and not in the context of giving a theory of holding others responsible. But it does seem fair to say that in the end Watson does not definitively endorse praise-or for that matter, our unexpressed attitudes of resentment and indignation-as ways of holding others responsible for their conduct. Perhaps it is best to characterize his view as one that puts sanctions at the center and leaves open the possibility that some unexpressed attitudes and praise could be thrown in for good measure. 


\section{Questions and confusions}

On my own view the most notable thing about the literature is just how many questions remain. For one thing, what should we say about praise? Does praise, like the range of sanctioning behaviors, serve to hold responsible? Wallace says no, most think yes. Wallace does little to motivate his choice, while those who think yes are largely motivated by the fact that praise, like blame, involves an attribution of responsibility. Perhaps even more perplexing is the trend in the literature that Watson points out. Many of those who do endorse praise as a way of holding responsible do so halfheartedly. They say that praise is a way of holding responsible, but then proceed in their examples and theorizing alike to focus on responses to those who have violated oughts as opposed to those who have met them; they focus on scolding and rebukes as opposed to thanks and applause. What's to explain these theorists' schizophrenic approach to praise?

Second, why does Wallace insist that holding responsible is situated "within a distinctive nexus of moral concepts, namely those of moral obligations, moral right and moral wrong" (Wallace 1996, p. 64)? In other words, what motivates his conviction that our practice of holding others responsible is exclusively a practice of the deontic rather than the evaluative realm? Watson, though not as explicitly as Wallace, also seems to endorse this idea. For him, to hold another responsible is to hold her to the "requirement" or "demand" she faces. These terms suggest that he sees holding another responsible as centrally about holding others to deontic rather than evaluative normative material. But what reason is there to think that reproving another for her wrongdoing is an instance of holding responsible, but criticizing another's bad conduct isn't? Responsible agents are, after all, just as responsible for their bad actions as they are for those that are wrong. It thus seems odd that we hold others responsible for the latter but not the former.

Third, we might wonder about the status of unexpressed reactive attitudes and normative expectations. If I keep my indignation buried in my heart, if I bite my tongue and do not express my resentment, if my normative expectation remains unvoiced, have I held another responsible? As we saw above, many theorists implicitly endorse the idea that our unexpressed reactive attitudes are holding engagements. Wallace does so explicitly and adds normative expectations to the list. But Watson senses a tension in this idea. On his view, given that unexpressed resentment and indignation are not straightforwardly sanctions, they do not straightforwardly serve to hold another responsible for her conduct. Yet is holding responsible truly to be understood as exhausted by sanctioning behaviors? Is that the sum total of what the practice of holding responsible amounts to?

Finally and perhaps most fundamentally, what, at the end of the day, should we make of the connection between holding others responsible and occupying Strawson's participant stance? Given how indebted the literature is to Strawson's seminal article, one might well wonder. Yet Strawson himself never addresses the question: indeed, he never once uses the phrase 'holding responsible' in the essay. And for every theorist like Wallace or Watson who defends a narrowed conception of holding responsible, there are writers such as Korsgaard, who vacillates between using the term "holding responsible" to refer to the very broad attitude of regarding someone as a responsible 
agent - a notion that seems very close to Strawson's participant stance — and using it to point to a very specific sort of activity, such as punishing or reproving someone for her wrongdoing (Korsgaard 1996). We face, then, a question about the relationship between holding responsible and the participant stance. It is obvious that they are intimately related, but it remains unclear what exactly this relationship amounts to. Are they equivalent? Is the former a part of the whole?

\section{Two faces of holding others responsible for their conduct}

The above highlights several questions about holding others responsible: Does praising another count as an instance of holding her responsible for her conduct? Is Wallace correct that holding responsible is situated "within a distinctive nexus of moral concepts, namely those of moral obligations, moral right, and moral wrong" (Wallace 1996, p. 64) or does the practice span both the deontic and evaluative realms? Does normatively expecting that someone do as she ought, or resenting her for her wrongdoing, count as an instance of holding responsible when we keep these attitudes to ourselves?

We can make progress toward answering these questions, I want to argue, by disentangling two different faces of holding others responsible for their conduct, each of which is important in its own right, but which shouldn't be confused.

On reflection, many of the phenomena explored above, discussed by Strawson and contemporary theorists, are phenomena about appraisal. We feel a reaction to someone's action; we express a reaction. I resent my brother for not coming to help me move as promised; I disapprove of my friend for her failure to finish what she started. I express my gratitude in a heart-felt thank you or my approval in words of recognition: "That was a truly lovely thing to do." Or again, to my brother, I say, "You are a class-A jerk!"

One important thing that Strawson and others point to, then, is a particularly deep form of moral appraisal, either privately held or publicly expressed. These are appraisals that differ from or go beyond mere beliefs that a person acted rightly or wrongly, well or badly. Instead, they are forms of emotional reaction that mark the moral meaning of others' morally significant actions.

On this face of holding responsible, notice, the positive and negative forms are equally valid - and equally important. Praise is, after all, just as much a form of moral appraisal as blame. I hold another responsible for her conduct when I feel gratitude for her help or when I approve of her generous action, just as much as when I resent her for her forgetfulness. And on this face of holding responsible, private emotions are as much holdings as are their more public expressions. Appraisal, after all, is accomplished whether it is shared or not. And finally, on this face our practice of holding responsible extends over the entire moral realm. We morally appraise others' virtues and vices, not just their deontic violations.

But if some of the elements discussed by Strawson and contemporary theorists are best thought of as deep appraisals, another set of them aims at something quite different. Imagine that your sister is having a difficult time at work. One of her co-workers is walking all over her. He treats her like a subordinate, leaves her 
holding the bag when things go wrong, and takes all the credit when success comes their way. Instead of saying something, your sister keeps her resentment bottled up inside. She fantasizes about giving her co-worker a piece of her mind but somehow never works up the courage to do it. Watching this drives you crazy. Unlike your sister, you have no trouble speaking your mind: "Stop being so passive! Don't let him treat you like that! Stand up for yourself! Hold him responsible, damn it!"6

If moral appraisal is all there is to holding another responsible, then your remark makes no sense. Why would you urge her do something she is already doing? But it does make sense because what you have in mind is not moral appraisal but what we might call holding accountable.

The core of this notion of holding responsible, I want to argue, is found in the metaphor of holding someone to the oughts that bind them. And this notion, I want to urge, is best understood on the model of enforcement. We hold another accountable when we perform a communicative act with a distinct internal aim, mode of achieving it, and success conditions. Take, for example, punishments and reproofs. The internal aim of these sanctioning behaviors is to induce what we might call first-personal practical uptake of the ought-violation in the one we're holding accountable- to get the wrongdoer to acknowledge her wrongdoing, feel remorse, apologize, make amends, and commit to doing right in the future. ${ }^{7}$ It achieves this aim by imposing burdens - the pain of punishment, the sting of reproof. A punishment or reproof is fully successful if it is met with full first-personal practical uptake of the oughtviolation; partial success is found, for instance, in reparation without regret, or again in an insincere apology. These are forms of degraded success. ${ }^{8}$ To see more clearly what I am getting at, imagine that you are an avid environmentalist taking a walk with your friend. As you stroll along, your friend takes out a candy bar, unwraps it, and

\footnotetext{
${ }^{6}$ I am indebted to Gary Watson for this example.

7 Although they use it in a different context, the phrase "first-personal practical uptake of the ought" is borrowed from Kukla and Lance (2009).

${ }^{8}$ See Duff (1986). I have been deeply influenced by Duff's account of reproofs. Though Duff does not use this terminology, he argues that reproofs internally aim at first- personal practical uptake of the oughtviolation in the one being reproved. He also points out that the sting of reproof is one of the modes by which a reproof might achieve its internal aim.
}

The pain which I suffer merely from the hostile reactions of others may, however, assist my recognition of my own guilt. My distress at the anger or contempt which they exhibit towards me may lead me to ask why they should react in this way; to see their reactions as a moral response to my conduct; to accept the justice of the judgment which that response expresses, and thus to suffer the pain of guilt and remorse. Their condemnation at first causes me a pain which is only contingently related to my wrong-doing, but it may be transformed into the kind of pain which is the proper end of moral blame. (Duff 1986, p. 59)

One of the main differences between Duff and myself is that for me it is part of the definition of a reproof that it achieves its aim in part by imposing burdens on the object of the reproof. Duff recognizes that the sting of a reproof might help a reproof achieve its aim, but Duff does not make this part of what makes a reproof a reproof, rather than, say, the speech act of moral persuasion. In fact, he thinks reproofs are acts of moral persuasion. On my account to morally persuade someone that she has done something wrong is one thing, and to reprove her, another. To be sure, these speech acts both internally aim at first-personal practical uptake of the ought-violation, but the mode by which each achieves this aim is different. Reproofs achieve this aim in part by imposing burdens on the one reproved; not so with moral persuasion. 
blithely throws the wrapper on the ground. Appalled, you lay into him; you reprove him. Your reproof is, I want to argue, a distinctive kind of act. It is a communicative act that aims at inducing in your friend first-personal practical uptake of his wrongdoing. The point of your speech act is to get your friend to recognize that he has done wrong, to feel remorse, to apologize and make amends, and to commit to not littering in the future. And it does this, not by merely pointing to or highlighting the ought-violation-displaying it or calling his attention to it. It does so, instead, by imposing burdens on your friend-in this case, the sting of the rebuke.

Of course, punishments and reproofs occur after the fact. Though less noticed, enforcement also has a forward-looking dimension. ${ }^{9}$ When infractions are threatened, we don't always sit idly by, letting people do as they please. Sometimes, if we anticipate that someone might flout the ought that binds her, especially when the stakes involved in someone not doing as she ought are high, we hold others accountable before they act.

Thus imagine you are walking down the street with that same friend, whom by now you know to be a serial litterer. This time you are on the lookout. You see him take out a candy bar, unwrap it, and start to throw it on the ground, and you turn proactive. You act, not in response to his wrongdoing, but to forestall it: you might bark, "Don't!", demanding that he not throw the wrapper on the ground.

The first thing to notice about your demand is that it is importantly different from many of the demands that pepper the speech act literature. The kind of demand that is most often featured in the speech act literature is what Rebecca Kukla and Mark Lance call a constantive demand (Kukla and Lance 2009, Chap. 5). Think of a sergeant demanding that his soldiers drop and do fifty pushups. When the sergeant issues his demand, he constates new normative material. He makes it the case that his soldiers ought to do something that prior to his demand they faced no requirement to do. He, metaphorically speaking, lobs an ought at his soldiers. Something different is going on when you issue your demand. After all, here you insert yourself into an already saturated normative context: your friend ought not throw the candy bar wrapper on the ground whatever you bother to do.

Here the demand is in the class of what Kukla and Lance call alethic demands (Kukla and Lance 2009). When you issue your demand, you are not constating a new ought or requirement; rather, you are taking the already existing burdens of morality and, as it were, second-personally imposing them on your friend. You are "taking morality's burdens and rendering them interpersonal." 10 As the above metaphors suggest, your demand adds a new, relational, dimension to the normative material your friend faces. If your friend now goes ahead and throws the wrapper on

\footnotetext{
9 Watson (1993) suggests that there might be a forward-looking dimension to holding responsible. In the course of discussing Ghandi and King, he makes the following claim: "Nor does it seem plausible to suppose that they do not hold themselves or others morally responsible: they stand up for themselves and others against their oppressors; they confront their oppressors with the fact of their misconduct, urging and even demanding consideration for themselves and others" (p. 148). Watson does not pursue this line of thought any further.

${ }^{10}$ Mark Lance used this apt turn of phrase in conversation with me.
} 
the ground, he will now not only as it were be violating morality's strictures, but he will also be disrespecting you. ${ }^{11}$

Notice then that your demand is in many respects like a punishment or reproof. Like a punishment or reproof, it is a communicative act that imposes burdens. Here the burdens imposed are of course not welfare burdens, but normative burdens. The internal aim of your demand also parallels the internal aim of a punishment or reproof. Whereas punishments and reproofs aim at first-personal practical uptake of an ought-violation, your demand internally aims at first-personal practical uptake of the ought by the object of your demand. Your demand aims at getting your friend to do what he ought to do and do it because he ought - that is, to not litter because he ought not litter. On this view, then, your demand is an alethic demand that secondpersonally imposes normative burdens on your friend with the aim of inducing in her first-personal practical uptake of the ought that binds her. I will call these demands "holding demands." They are, on my view, the forward-looking analogue of punishments and reproofs.

Holding another accountable, then, has both a backward- and a forward-looking leg. The backward-looking leg is the leg of punishments and reproofs; the forwardlooking, the leg of holding demands. These enforcement mechanisms are communicative acts that impose burdens - the forward-looking impose normative burdens, and the backward-looking impose welfare burdens. They all also aim at getting the object of the communicative act to take responsibility for her conduct. In the case of holding demands, "taking responsibility" amounts to first-personal practical uptake of an ought, which means doing what one ought because one ought. In the case of punishments and reproofs, taking responsibility amounts to first-personal practical uptake of wrongdoing, i.e., recognizing one's wrongdoing, feeling remorse, apologizing, making amends, committing to doing what one ought in the future.

If this picture is correct, then neither our unexpressed reactive attitudes nor our normative expectations serve to hold another accountable for her conduct. Unexpressed attitudes do not hold others accountable because they are not communicative acts. Praise does not hold another accountable, either, but for a different reason. Our practice of holding others accountable is exclusive to the deontic realm: holding another accountable is an engagement around an ought. Praise and oughts are a mismatched pair. We do not praise others merely for not doing wrong. We don't praise people for not killing, for not stealing, for not spitting in people's faces (Wallace 1996, pp. 71-72).

In saying this, I do not mean to suggest that we praise people only for conduct that exceeds or goes beyond duty in some way-for the supererogatory. Angela Smith expressed this view but I think it is wrong. Smith says:

In the case of positive moral appraisal, the claim is that the person has gone 'above and beyond' what is morally required of her in some area. To praise someone as 'generous' or 'thoughtful,' for example, is to claim that she regularly or in some particular instance has given extraordinary attention to the needs and interest of others in her attitudes and actions. (Smith 2008, p. 381, italics mine)

\footnotetext{
11 The ideas in this paragraph are the result of many conversations with Mark Lance, Rebecca Kukla, and Maggie Little. These ideas are also presented in Little \& Macnamara (n.d.).
} 
To see why I think this is mistaken, consider the following example, borrowed from Julie Driver. A young man is boarding a crowded train, but to his great delight he finds the one double seat left on the train and happily takes it. Just as the young man is settling in, an elderly couple approaches and explains that they are very nervous about traveling and that it would be such help if they could sit together. They politely ask him if he will move to another seat on the train so that they can sit together. $^{12}$

On my own view, moving is not supererogatory; the man would be wrong not to move. Given how little is involved in moving and how much it will help the elderly couple, the gentleman would be wrong not to do so. To be sure, he was looking forward to the luxury of having two seats all to himself, but doing what one ought to do, we all know, can be burdensome. At the same time though, I think that if the man does move, the elderly couple ought to be grateful and thank him for his kindness. And if I were on the train witnessing this encounter, I would try to catch the young man's eye and smile at him approvingly. In short, the young man's action warrants praise.

But why, if he is merely doing what he ought to do? I think we are inclined to praise him here because moving is not only deontically significant, but also evaluatively significant. Moving is an action that is not only right, that is, not wrong, but also kind, generous, considerate-good. This overlap of deontic and evaluative significance occurs often in the moral life. And when it does, it is the good in the action and not its deontic status that we are responding to with praise. Broadly put, my claim is that praise is always a response to the positive evaluative significance of an action.

If praise is always a response to the positive evaluative significance of an action, and to hold another accountable is to engage her around an ought, then there is a principled reason for thinking that praise does serve to hold another accountable.

But what about when we respond to someone's ought-violation with a form of expressed negative moral appraisal? For example, if I express the resentment I feel towards my brother for not helping me move as promised by saying to him, "You're a class-A jerk!" have I held him accountable for his conduct?

I don't think so. This speech act, and more broadly all forms of expressed moral appraisal, is not an enforcement mechanism - these speech acts do not aim at firstpersonal practical uptake of an ought-violation and achieve this in part by imposing burdens on the one being held responsible. When I say to my brother, "You're a class-A jerk!", I am performing a speech act with an expressivist aim: that is, the essential point of this speech act is to express my resentment. To be sure, when I issue my speech act I may want or hope that my brother will see the error of his ways and sincerely apologize, but my hope and wants are not the same thing as the essential aim of the speech act. The essential or internal aim of a speech act should not be confused with the purposes or aim of the speaker in uttering it (see Kukla and Lance 2009, pp. 13-14; Searle and Vanderveken 1985, pp. 13-14). Consider, for example, the speech act of promising. When I promise to do something "I may do

\footnotetext{
12 I borrow this example from Driver (1992, pp. 286-288). Driver herself defends the view that this case points to cases of actions that are bad but not wrong. I think that conclusion deeply misguided-see Little \& Macnamara (n.d.).
} 
so because I may want to reassure the hearer, keep the conversation going, or try to appear to be clever, and none of these is part of the essence of promising." The internal aim of promising is to bind oneself to a future course of action (Searle and Vanderveken 1985, pp. 13-14) Similarly, when I say to my brother "You're a classA jerk!", I may do so because I want him to recognize the error of his ways and apologize, but this is not the essential aim of my speech act. The essential aim of my speech act, as with all forms of expressed moral appraisal, is to express the underlying reactive attitude.

In contrast, the internal aim of punishment and reproof $i s$ first-personal practical uptake of the ought-violation. But when I say this I do not mean to imply that these enforcement mechanisms do not express feelings of resentment and indignation. If you are an avid environmentalist you no doubt swell with disapproval when you see your friend litter, and your reproof no doubt serves to express this disapproval. My point here is simply that your reproof does not have an expressivist aim. On my view, the relationship between the disapproval or indignation you may be feeling and your reproof is, broadly speaking, akin to the relationship between belief and assertion. Just as our assertions often give voice to our beliefs, so too, our reproofs give voice to our disapproval or indignation. But just as the aim of assertion is to describe how things are, rather than to express beliefs, so, too, our reproofs aim at inducing in the one being held accountable first-personal practical uptake of her ought-violation, not at expressing disapproval or indignation.

Theorists often insist on the difference between uncommunicated and communicated responses to wrongdoing (see for example, Scanlon 1998, p. 269). The above is urging a different distinction-a distinction among communicated responses to wrongdoing. There are communicated responses to wrongdoing that internally aim at expressing our reactive attitudes-you say to the date who stands you up for the second time, "Drop dead! You make be sick!" —and there are communicated responses to wrongdoing that are enforcement mechanisms. When your date stands you up for the second time you scold, reprimand, or rebuke him; you say, "You are a very rude person. A decent person has the courtesy to make a simple phone call!" The former class of responses I want to argue, populate the appraisal face of holding responsible, the latter the accountability face. ${ }^{13}$

\footnotetext{
${ }^{13}$ Scanlon (1998) distinguishes enforcement mechanism and moral appraisal. Much of what he says suggests that he thinks enforcement mechanisms are associated with the desert thesis, that is, "the idea that when a person has done something morally wrong it is morally better that he or she should suffer some loss in consequence" (p. 274). On my view, there is no essential connection between enforcement mechanisms and the desert thesis.

According to Scanlon, moral criticism calls on the person criticized to acknowledge wrongdoing and apologize or to justify or explain. As Smith puts it: "Moral criticism by its very nature seems to address a demand to its target. It calls upon the agent to explain or justify her activities in some area, and to acknowledge fault if such a justification cannot be provided" (p. 381).

While I am uncomfortable with the claim that our moral criticisms "address a demand," I am attracted to the idea that that we appropriately acknowledge others' moral criticism by explaining or justifying our activities or by acknowledging fault if a justification is lacking. Perhaps this is all that Scanlon and Smith mean when they say that moral criticism "calls on" the agent to justify or explain or acknowledge wrongdoing. This is consistent with my claim that the internal aim of moral appraisal is to express the underlying reactive attitude. The internal aim of a speech is one thing, the appropriate acknowledgement of a speech act another.
} 
There are, then, two faces of holding others responsible for their conduct. On the moral appraisal face we find those reactive attitudes that are forms of praise and blame. In contrast, behaviors designed to enforce against infraction of moral oughts lie at the heart of holding accountable. Both faces are deeply important and deserve our attention. Moral appraisal is important because it is the primary way in which we affectively register and express the moral meaning of others' morally significant actions; accountability because it is a key piece of the morally deontic realm, intimately tied to what is involved in classifying an action as non-optional.

If the above is correct we have our answers to the questions posed at the beginning of this section. Does praising another count as an instance of holding her responsible for her conduct? On the appraisal face, yes; on the accountability face, no. Is Wallace correct that holding responsible is situated "within a distinctive nexus of moral concepts, namely those of moral obligations, moral right and moral wrong" (Wallace 1996, p. 64)? From the perspective of deep moral appraisal, no; from the perspective of accountability, yes. Does normatively expecting that someone do as she ought, or again resenting her for her wrongdoing, count as an instance of holding responsible when we keep these attitudes to ourselves? On the accountability face, no unexpressed attitudes serve to hold responsible. On the appraisal face, normatively expecting that someone do as she ought does not count. But the opposite is true for resentment, and for that matter all the reactive attitudes that are forms of praise and blame. These attitudes are forms of moral appraisal even if they are never expressed.

Distinguishing appraisal and accountability, and highlighting their features, not only helps to answer the questions engendered by the literature, but also provides us with a compelling explanation of why the literature engenders the questions it does. It's no wonder that theorists disagree about the status of praise, the status of unexpressed attitudes, and the deontic/evaluative issue. One's views on these questions depend upon whether one has the accountability or appraisal face in mind. Some theorists have the former in mind, others the latter, and some move in the course of their discussion from one face to another.

I develop this last point in greater detail in Sect. 6, but for now we can see some of its force by recalling that while most theorists initially endorse praise as a way of holding another responsible, they proceed in their examples and theorizing alike to focus exclusively on blame. Watson chalks this phenomenon up to meanspiritedness and the greater stakes involved in blaming another; and to be sure these may be part of the story. But it is also possible that theorists include praise only to soon leave it behind because they begin with the moral appraisal face in their minds and then somewhere in the course of thought inadvertently shift their focus to the decidedly negative accountability face.

Footnote 13 continued

Scanlon and Smith's insights do highlight the fact that my accounts of both enforcement mechanisms and moral appraisal are incomplete. There are numerous dimensions along which we can analyze speech acts (Searle and Vanderveken 1985; Kukla and Lance 2009). My accounts highlight only a few of these many dimensions. For a fuller account of communicated responses to wrongdoing see Macnamara (n.d.). 


\section{The participant stance and holding others responsible}

I now want to turn to one last confusion engendered by the literature: What is the relationship between holding responsible and the participant stance? Here too a distinction between two senses of holding responsible-albeit a different one from above-will bring into sharp focus the answer.

Theorists interested in being responsible frequently distinguish being a responsible agent - that is, being someone who possesses the capacities needed to be a member of the normative community-from being responsible for a particular piece of conduct (see for example, Fischer and Ravizza 1998). Both the accountability and appraisal faces correspond to the latter notion of being responsible. All of the above examples, whether of appraisal or accountability, centered around someone's specific action: standing someone up, performing a kind act, breaking a promise. There is, though, another sense of holding someone responsible that corresponds to the first way of being responsible-being a responsible agent.

Sometimes, when speaking of holding people responsible, what we have in mind is a broad way of regarding people. We hold others responsible, in a modest and rather diffuse sense, when we view them as a "term in a moral relationship," "a member of the moral community" (Strawson 1993, p. 59). Whether or not our orientation is explicitly moralized, we view them in a way that essentially relies on attributing to them the basic capacities of agency. We ask for reasons, rather than simply manipulate; we respond to others' triumphs with admiration rather than scientific assessment; we throw them in jail as a punishment and not just as an act of self-protection.

This is the sense of holding responsible that Strawson was interested in. Recall, to take up Strawson's participant stance toward another is to regard her as a responsible agent. And regarding her in this way guides our presumptive interpretations of her conduct and structures our behavioral dispositions and emotional proclivities. In particular, it leaves us susceptible to feeling the whole range of Strawsonian reactive attitudes. When theorists such as Korsgaard talk of holding responsible in these terms, there is, then, a reason: we do sometimes use the phrase to contrast our usual orientation with the objective stance that Strawson discussed.

It is clear, then, that there is a sense of holding responsible that is indeed equivalent to the participant stance. It is also clear that when we hold another responsible for a specific piece of conduct holding responsible is not equivalent to the participant stance. There is a difference between a broad orientation that involves, at core, a disposition to regard an agent as a responsible entity, on the one hand, and reactions or engagements that have at their core to do with reactions to and engagements around specific actions.

But while the participant stance on the one hand, and our practices of moral appraisal and holding accountable on the other, are not equivalent, they are intimately connected. When we adopt the participant stance toward another we are poised to come to certain beliefs about the person, to feel certain emotions, to interact with her in various ways. Among the many things we are poised to do is morally appraise and hold her accountable. The activities and attitudes that 
constitute these practices are, as it were, things that the participant stance leaves one primed to do.

But one would be deeply mistaken to think that the attitudes and activities of the appraisal and accountability faces are the only things that taking up the participant stance towards another leaves one primed to do. When we regard another as a responsible agent rather than an object, we are also poised to offer her confidences, accept her promises, exchange vows with her, and fall in love with her. While we don't take up these attitudes towards or interact with objects in these ways, they are just the sorts of things we do with responsible agents. At the same time, none of these attitudes or modes of interaction serve to hold another responsible for her conduct. It is one thing to offer another confidences, accept her promise, exchange vows with her, fall in love with her, on the one hand, and quite another to morally appraise or hold her accountable.

Indeed, moral appraisal and holding accountable are merely two of the many ways we engage with others as responsible agents around their good, bad, virtuous, vicious, right or wrong conduct. Consider this true story from my early years. Right after I graduated from college, I taught for 2 years as a seventh grade science teacher in New York City. One day I spotted my student, Tammy, winding up to throw a beaker across the science lab. In response to this delicate situation, one thing I could have done was to get Tammy's attention and launch into an explanation of why one should not throw beakers. I could have pointed out that throwing beakers is dangerous, that she might hurt someone; that, even if she manages not to hurt anyone, throwing the beaker across the room will break it; that to intentionally break lab equipment is inconsiderate. In short, I could have tried to get her to see and appreciate the reasons that together speak in favor of putting the beaker down; I could have tried to persuade her that she ought not throw a beaker in the lab. But that is not what I did. What in fact I did was say, in an authoritative tone and with that stern "teacher look" I perfected during my tenure in the seventh grade, "Tammy, put the beaker down." My own bet is that my choice of method was the right one.

Consider another example. You find out that your friend cheated on a test. There are many ways you might respond to her as a responsible agent. You might disapprove of her, or demand that she never do so again. But you also, and instead, might help her figure out why she cheated. You might try to convince her that she can succeed without cheating, or, more concretely, help her study for future tests. Only the first two responses are forms of either moral appraisal or holding accountable.

The picture I am urging here is one of three concentric circles of participant attitudes and activities. The largest circle is populated by all those attitudes and activities that go hand in hand with regarding another as a responsible agent rather than an object. The next circle just inside is measured by all the ways we engage a responsible agent around her good, bad, virtuous, vicious, right or wrong conduct. And the inner-most circle is occupied by those attitudes and activities that serve to hold another responsible for her conduct. Offering another confidences, accepting her promises, exchanging vows with her, and falling in love with her fall within the outermost circle but outside the inner two. Asking someone for the reason behind 
her action, or trying to help someone see the reasons why a particular action might be ill advised, fall inside the outer two circles but outside the innermost. And finally, those attitudes and activities that are forms of moral appraisal or again holding accountable populate the inner most circle and thus fall within all three.

Strawson himself insightfully taught us that we travel, in everyday life, between the participant and the objective stances. Indeed, we shift between the stances, not just when shifting from encounters with agents and non-agents. Even when we are interacting with capacitated agents, he pointed out, we can, for short periods, "as a refuge, say, from the strains of involvement; or as an aid to policy; or simply out of intellectual curiosity," move from the participant to the objective stance (Strawson 1993, pp. 52-53). What the above highlights is that we not only can travel between stances but within the participant terrain itself.

\section{Wallace revisited}

Over the past two sections, I have argued that we hold another responsible in one sense when we take up the participant stance toward her, and in another when we hold her responsible for a particular piece of conduct. I emphasized the broadness of the participant stance and how vast and varied our participant attitudes and activities are. Further, I urged, our practice of holding others responsible for a particular piece of conduct is a genus with two species-deep moral appraisal and accountability. The core of the latter notion is found in the metaphor of holding someone to the ought that binds her. And this notion, I urged, is best understood on a model of enforcement. This face is centrally made up of punishments, reproofs, and holding demands. At the heart of the appraisal face, in contrast, are those reactive attitudes that are forms of praise and blame. To feel these reactive attitudes or again to perform a speech act that essentially aims at expressing them is, on this face, what it is to hold another responsible for her conduct.

I now want to argue that if this picture of the terrain helps to clarify the different sorts of practices, it helps us to reveal an awkwardness in Wallace's account. According to Wallace, we remember, holding others responsible is constituted by certain key, negative, reactive attitudes that orient to the deontic: we hold another responsible whenever we normatively expect that she do what she ought to do, resent her or feel indignation toward her when she does not do so, or express these reactive attitudes in some sort of sanctioning behavior. While those sanctions, where they occur, are important, they are for him the handmaids of the reactive attitudes. For Wallace, the real point of such responses as avoidance, denunciation, reproach, censure, and the like is to express resentment and indignation.

We can now see, though, that, taken as a theory of holding others responsible for their conduct, this particular grouping of features is a rather strange one. The fact that reactive emotions are such a strong focal point for Wallace suggests that what he has in mind is our practice of deep moral appraisal. But if this is right, then why not include praise as a constitutive element? Why assume the practice is situated exclusively in the deontic realm? And what is to explain his focus on normative expectations, which are forward-looking and thus not forms of moral appraisal? 
Given his exclusion of praise and his insistence that holding responsible belongs solely in the deontic realm, perhaps we should read his theory as one of the accountability face. But if this is right, it would be strange indeed to say that merely feeling resentment or indignation amounts to holding another responsible. Whatever else private emotions do, they do not in themselves affect others.

Of course it might be that we need only to feel guilt to hold ourselves accountable - as Wallace puts it, "a hair shirt need not be deployed" (Wallace 1996, p. 57). But this is consistent with everything I have thus far said. There are crucial differences between unexpressed other-regarding reactive attitudes and unexpressed self-regarding such attitudes, not the least of which is that to feel guilt is a form of self-enforcement. Guilt does not need to be 'expressed' in order to count as holding accountable because it does not need to be expressed in order to count as an act of enforcement.

And again, if the theory is really meant to capture the idea of holding accountable, why say that the real point of responses such as avoidance, denunciation, reproach, censure and the like is to express resentment and indignation? Even if accountability has an expressivist import, the engagements that make up the practice internally aim not at expression, but at getting their objects to take responsibility for their conduct.

In short, Wallace's theory, taken literally, correctly describes neither the accountability nor the appraisal face of holding responsible. His account looks rather like mishmash - it takes some features from the accountability face and some from the appraisal face and throws them together. Without distinguishing appraisal and accountability, his delineation of the scope of our practice appears rather arbitrary.

Does this mean that Wallace's theory is bankrupt? Far from it. What Wallace's account really gives a theory of, I want to argue, is the moral psychology associated with holding others accountable, that is, the important first-personal, subjective phenomenology that accompanies the activities and engagements of holding others accountable. From a vast array of participant attitudes, Wallace zeros in on three as of crucial importance to our practice of holding others responsible: normative expectations, resentment, and indignation. This fact is striking because these three attitudes are connected to the enforcement mechanisms found at the heart of accountability.

Start with resentment and indignation. Recall my brother not helping me move as promised. I may express my resentment in many ways: by calling my sister and complaining, or by going straight to the source. To my brother I may, for example, say "You're a class-A jerk," in other words I may perform a speech act that internally aims at expressing my resentment. Or I may reprove him: with authority, I say, "This sort of behavior is appalling; it is unbelievable that you are 28 years old and can't manage to keep a simple promise!" The latter sort of response I have urged internally aims not at expressing resentment, but rather at prompting firstpersonal practical uptake of the ought-violation. There are a variety of ways one might express her resentment, or again indignation. Among these are punishments and reproofs. We sometime express our resentment in sharp words of rebuke, our indignation in long-winded reprimands. 
A similar relationship holds for normative expectations and holding demands. ${ }^{14}$ One important way in which our normative expectations find their voice is through holding demands. I may express my normative expectation that my friend not litter by saying "Don't!" Or again, my normative expectation that my daughter not break her promise to her sister by saying "Do not break the promise you made to your sister!" 15

What this suggests is that, from the many and varied participant attitudes Strawson talked about, Wallace zeroed in on those that make up the psychological underpinning of the enforcement mechanisms that constitute our practice of holding others accountable. To my mind, this is Wallace's main insight. To a greater extent than other theorists, Wallace underscores the importance of our normative expectations. And he is the only theorist to explicitly argue for the special importance of just two of Strawson's reactive attitudes: resentment and indignation. In other words, Wallace does a far better job than any other theorist at pointing us towards the moral psychological underpinnings of our practice of holding accountable.

However, I do not think resentment, indignation, and normative expectations make up the heart of one of the faces or forms of holding responsible. Viewed from the perspective of appraisal, there is no reason to single out resentment and indignation over praise, or again the deontic over the evaluative; viewed from the perspective of accountability, there is no reason to countenance emotions kept

\footnotetext{
14 Above I distinguished normative expectations from predictive expectations and from the belief that someone ought to phi. It is also important to distinguish normative expectation from the participant stance. When Aidan eschews his normative expectation, he does not eschew the participant stance. Aidan still regards his fellow subway riders as responsible agents. It is not as though he would be free from feelings of resentment or indignation whatever his fellow riders do. If, for example, a fellow rider shoves another passenger out of the way to get to an open seat first, Aidan's blood will start to boil. And he still presumes - until presented with evidence to the contrary - that his fellow passengers are responsible for their conduct, including the way they enter the subway car. More broadly, he still approves of the person who offers the elderly man his seat, admires another for the particularly well-mannered way in which she boards the subway, and he might even (and wouldn't this be lovely) fall in love with someone on the subway. The participant stance is a broad psychological orientation; it is a way of regarding whole persons, and one that has wide-ranging implications for one's presumptive interpretations, behavioral dispositions, and emotional proclivities. A normative expectation, in contrast, is a far more discrete and directed attitude: it is indexed to a specific ought—in Aidan's case, the ought of waiting one's turn to board the subway.

A normative expectation may not be identical to the participant stance but it is, like our reactive attitudes, a participant attitude. Our normative expectations just like our reactive attitudes go hand in hand with regarding another as a responsible agent, as opposed to an object or someone incapacitated in some or all respects for ordinary interpersonal relationships. In specific instances, we can like Aidan, stop normatively expecting something from someone we regard as a responsible agent, but these cases are the exception.

15 Wallace (1996, p. 22) writes, "We might express an expectation by using the concepts of prohibition or requirement explicitly, say as on operator on sentences that describe kinds of action in a particular situation (for instance: "It is prohibited that you should break the promise made to your sister"). Alternatively, expectations might be expressed by imperatives ("Do not break the promise you made to your sister"). In this quote, Wallace acknowledges that normative expectations are expressed in demands. He of course does not specify that these are holding demands, rather than constative demands, but then again, he did not have the distinction ready to hand.
} 
locked in one's heart as an instance. To be clear, then, none of this suggests that I agree with Wallace's motivation for singling out resentment and indignation on the one hand and normative expectations on the other. For him, these attitudes take on importance because of their conceptual connection to each other. In contrast, for me, the distinctive relevance of these attitudes is found in their connection to our enforcement mechanisms: resentment and indignation are often expressed in punishments or reproofs, and normative expectations in holding demands.

I also don't agree with Wallace's claim that Strawson gets the extension of our class of reactive attitudes wrong (Wallace 1996, pp. 25-33). I think Wallace is mistaken to think that we need to narrow the class of Strawsonian reactive attitudes to resentment and indignation. I conjecture that Wallace's claim is the result of his failure to clearly distinguish between holding responsible as regarding another as a responsible agent and holding someone responsible for a discrete action. Strawson sets out to give an account of the former. Wallace, in contrast, sets out to give an account of the latter. If Wallace had at the forefront of his mind the distinction between these two senses of holding responsible he would have seen that Strawson and he were giving accounts of two different things. And if he saw this, he would not have been tempted to think he needed to revise Strawson's position in order to make the points he wanted to make. He could have acknowledged that the class of Strawsonian reactive attitudes is wide-ranging, including, as Susan Wolf aptly put, all those emotional reactions one has toward individuals "insofar as one views those individuals as persons" (Wolf 1981, p. 390), and then gone onto highlight a special class of the reactive attitudes - consisting of resentment and indignation. If I am right about the significance of these attitudes, we might call them "accountability reactive attitudes" or some such thing.

Details aside, I do think Wallace was onto something. His account of holding others responsible for their conduct puts us on our way toward a better understanding of the moral psychological underpinnings of our practice of holding others accountable. This might not be precisely what he intended to do, but it is what he did accomplish.

I began with literature and the questions and confusions it engendered. Broadly speaking I responded to these questions and confusions by presenting a picture of our practices of holding responsible. My picture is no doubt incomplete-more hard philosophical work must be done before we have a complete account of this terrain-but even at this stage it has revealed the awkwardness and insight in Wallace's account, the richness of our practices, and the fact that our practices deserve far more attention than they have as of yet been given.

Acknowledgements Previous versions of the above were presented to audiences at a University of California at Riverside Agency Workshop, and the 2009 Imagination Workshop at Yale University; thanks to all who joined in the discussions. I would also like to thank members of my 2008 UCR graduate seminar "Holding Others Responsible". Thanks, too, to Mark Lance, Rebecca Kukla, Gary Watson, Andy Reath, Elisa Hurley, Nancy Sherman, Alisa Carse, Neal Tognazzini, Caleb Mason, Chauncy Maher, Justin Coates, Angela Smith, and Bill Bracken for helpful comments on and discussions of various versions of this paper. Special thanks to Maggie Little for many conversations on the issues discussed in this paper and for reading and commenting on countless drafts of this article. 
Open Access This article is distributed under the terms of the Creative Commons Attribution Noncommercial License which permits any noncommercial use, distribution, and reproduction in any medium, provided the original author(s) and source are credited.

\section{References}

Darwall, S. (2006). The second-person standpoint: Morality, respect, and accountability. Cambridge, MA: Harvard University Press.

Driver, J. (1992). The suberogatory. Australasian Journal of Philosophy, 70(3), 286-295.

Duff, R. (1986). Trials and punishments. Cambridge: Cambridge University Press.

Fischer, J. M., \& Ravizza, M. (1998). Responsibility and control. Cambridge: Cambridge University Press.

Korsgaard, C. (1996). Creating the kingdom of ends: Reciprocity and responsibility in personal relations. In C. Korsgaard (Ed.), Creating the kingdom of ends (pp. 188-221). Cambridge, MA: Harvard University Press.

Kukla, R., \& Lance, M. (2009). 'Yo!' and 'lo!': The pragmatic topography of the space of reasons. Cambridge, MA: Harvard University Press.

Little, M. (1998). Care: From theory to orientation and back. Journal of Medicine and Philosophy, 23, 190-209.

Little, M., \& Macnamara, C. (n.d.). Between the optional and the obligatory. Unpublished Manuscript. Macnamara, C. (n.d.) The public face of blame. Unpublished Manuscript.

Oakley, J. (1992). Morality and the emotions. London: Routledge.

Reiff, M. R. (2005). Punishment, compensation, and law: A theory of enforceability. Cambridge: Cambridge University Press.

Scanlon, T. M. (1998). What we owe to each other. Cambridge, MA: Harvard University Press.

Scanlon, T. M. (2008). Moral dimensions: Permissibility, meaning, blame. Cambridge, MA: Belknap Press of Harvard University Press.

Searle, J. R., \& Vanderveken, D. (1985). Foundations of illocutionary logic. Cambridge: Cambridge University Press.

Smart, J. (1961). Free-will, praise, and blame. Mind, 70(279), 291-306.

Smith, A. (2007). On being responsible and holding responsible. Journal of Ethics, 11(4), 465-484.

Smith, A. (2008). Control, responsibility, and moral assessment. Philosophical Studies, 138, 367-392.

Strawson, P. (1993). Freedom and resentment. In J. M. Fischer \& M. Ravizza (Eds.), Perspectives on moral responsibility (pp. 45-66). Ithaca: Cornell University Press.

Wallace, R. (1996). Responsibility and the moral sentiments. Cambridge, MA: Harvard University Press.

Watson, G. (1993). Responsibility and the limits of evil: Variations on a strawsonian theme. In J. M. Fischer \& J. M. Ravizza (Eds.), Perspectives on moral responsibility (pp. 119-148). Ithaca: Cornell.

Watson, G. (1996). Two faces of responsibility. Philosophical Topics, 24(2), 227-248.

Watson, G. (2004). Agency and answerability: Selected essays. Oxford: Clarendon Press.

Wolf, S. (1981). The importance of free will. Mind, 90, 386-405.

Wolf, S. (1990). Freedom within reason. Oxford: Oxford University Press. 